\title{
The development of small settlements in the industrial plant - city model - based on the examples of Nowa Dęba and Nowa Sarzyna
}

\author{
Anna Sikora ${ }^{1, *}$ \\ ${ }^{1}$ The Faculty of Civil and Environmental Engineering and Architecture, Rzeszow University of \\ Technology, Powstańcow Warszawy 12, 35-959 Rzeszow, Poland
}

\begin{abstract}
Double-purpose industrial plant-settlement complexes (city) are fairly popular urban combinations; especially so during the inter-war and post-war industrial periods, when through a decision by the central authorities, industrial facilities were located in specific areas which were then developed over time. Specific cases of such complexes are two small cities built from scratch around growing industrial plants. The article presents certain functional and spatial changes in two urban centers: Nowa Dęba and Nowa Sarzyna, which are located in the Subcarpathian Voivodeship.
\end{abstract}

\section{Introduction}

Double-purpose complexes in industrial plant-city (settlement) arrangements are fairly popular urban combinations, especially in inter-war and post-war industrial districts. They may often be found in the structures of fast-moving cities in the period of the developing socialist economy based on industry and as independent settlement units. While in the first case they are a part of the city, which is why they are not fully legible, in the case of small urban complexes, they constitute an interesting object for studying the dynamics of development of specific urban arrangements.

The plant-city model is a characteristic arrangement for the period of expansive industrial development and the model idea of Garnier's segregation of functions. Separated by wide belts of green or communication routes, the functions were to ensure comfort of living and organize the space in a formal and aesthetic manner. This idea was developed during the period of modernism and socialist modernism, when large-scale heavy industry and medium-machine industry were established in Eastern Europe. These investments were accompanied by equally large groups of housing structural units in simple composition systems, mainly comb and linear.

\footnotetext{
*Corresponding author: sikora@prz.edu.pl
} 


\section{The specificity of the industrial plant-city arrangement in the case of small settlement units}

A special case of such a system are arrangements identified in small towns, where an industrial zone composed of one or many enterprises is located away from the residential and service structure, creating a bipolar pattern that has never been disturbed by the growing urban tissue. It seems that when analyzing functional and spatial changes - formal, compositional and aesthetic changes taking place in such a unit during its existence, we can present their simplified typology.

The discussed cities were created near important deposits of raw materials such as coal or stone, or found "in cruda radice". In the case of most of the cities associated with mining, their development was relatively harmonious, from the time of cottage production in various historical periods to modern mechanical exploitation or reclamation. A group of these units developed in a natural way - according to the principle that the city is an organism that changes over time.

In the case of new cities - found "in cruda radice", location is connected with the specific need and/or implementation of a new urban idea. Very often these are isolated or even closed cities associated with arms production (Nowa Deba), machine and communication (Świdnik), as well as the military location of garrisons and training grounds (Borne-Sulinowo) or with the production of hazardous materials, e.g. chemical industry (New Sarzyna). As previously mentioned, cities in the plant-settlement model are connected with a precisely defined growth centre. Its function, usually homogeneous at the time of locating the city, may be transformed or fragmented over time, while retaining its original layout in relation to the residential and service part. These changes result from the rights of the free market, where companies are formed, go bankrupt or are divided but still, due to their field reserve and favorable location, are concentrated in one place.

In terms of communication, the discussed units are located off the main routes, rather near secondary roads. Their isolation is also influenced by the fact that due to their special functions they are often located in dense forest complexes, which may be a chance to develop functions other than industrial, e.g. tourist or recreation and leisure. In the immediate vicinity of the urban structure, hiking and cycling paths are marked out, as well as areas protected by forms of nature conservation.

\section{Industry and small towns in the Podkarpackie voivodeship}

\subsection{General characteristics}

In the Podkarpackie voivodeship, similarly as in the entire eastern part of Poland, there is the dominance of small cities, which are understood as settlement units with a population of up to 20000 . [1]. The region has agricultural traditions going back to the time when in the first half of the 20th century there was a civilizational leap related mainly to the initiation of the Central Industrial District project, when in the central part of the country, in the socalled security triangle, there were centers or locations, in which large industrial complexes were created for the purpose of increasing the defense of the newly created Polish country. In addition to investments inside the tissue of existing urban centers or in its vicinity, places for the construction of plants and sensitive estates have been identified. These were, for example, Nowa Dęba near the village of Dęba, Nowa Sarzyna in the area of the villages of Ruda Łańcucka, and Stalowa Wola built between Nisko and Rozwadów. In the western part of the province, near the village of the same name, the plastics factory developed together 
with the Pustków housing estate, which never received city rights, although it seems that it should be considered as such.

In the second half of the 20th century, Subcarpathia continued to develop mainly based on industrial production, which, however, was at a much lower level than in the centralwestern area of the country. In the 1960s, the western part of the voivodeship was defined the Rzeszów Industrial Area as type C - the industrialized area and the eastern one as D non-industrialized area (A-industrial districts, B-industrial areas, C-industrialized areas, Dnon-industrial areas) [2]. During this period, until the $1990 \mathrm{~s}$, driven by the socialist economy, the above-mentioned cities developed to change the structure of industry during the developing market economy and later to stabilize or stop their growth. Currently, the region is classified as low-industrialized [3, 4].

Ultimately, each of the new cities has developed with completely different results. Stalowa Wola has become a medium-sized, heavily industrialized city. The small cities of Nowa Dęba and Nowa Sarzyna remained, which differ in the character and quality of spatial changes. However, Pustków remained a complex of rural buildings along with a multi-family housing estate in the multi-family structural unit type.

\subsection{Development and spatial transformation of Nowa Dęba}

Nowa Dęba is a settlement unit found "in cruda radice" near the village of Dęba in dense complexes of the Sandomierz Wilderness. Originally, in 1927, a military training ground was located nearby, followed by investments recommended in the Four Year Plan by Eugeniusz Kwiatkowski: Ammo Factory No. 3 employing 360 people together with a housing estate for employees. Both the factory and the building complex could not be completed before the outbreak of World War II. The estate was divided into two parts: in the north there was a hospital, a primary school, a swimming pool, villas for managers and several multi-family buildings intended for the clerical staff, and a single-family housing estate for the foremen; and in the south there were blocks of flats for workers. All multifamily buildings were located in the north-south axis and arranged in a line. The foremen colony located slightly west, was characterized by a street layout with checkered twofamily buildings $[5,6]$.

In the $1950 \mathrm{~s}$, the manner of management changed, as well as the name of the factory changed to Metal Works. Employment increased to around 500 people, and up to 400 people lived on the factory estate. Simple, modernist-shaped buildings in a line arrangement were supplemented by buildings creating quasi-quarters with characteristic socialist realist and meandering aesthetics. One may even assume that the urban layout of Nowa Dęba is actually a system in the style of socialist modernism (socialist realism), because only in this form its composition is legible.

In 1961 Nowa Dęba estate obtained city rights. From that time, up to the 1990s, in the northern part, multi-family prefabricated buildings in comb systems were developing. The service offer also increased: the Mechanical Technical School, Primary School, nursery, cinema, sports club, market hall, and the Cultural Center, which currently serves as a central city landmark were built. The commercial and service network was expanded [6].

After 1990, growth clearly slowed down, investment activity was limited to individual residential and service investments and repairs to existing resources. The industry structure has been fragmented, mostly retaining its location. The Tarnobrzeg Euro Economic Zone Wisłosan Park was created, which included Nowa Dęba. The most important companies located in the industrial area, in addition to DEZAMET Metal Works are: Pharmaceutical Plant Polpharma, Northem Aerospace dealing with aviation production, Unidez manufacturer of heating elements, Profund dealing with metal processing and several smaller companies. 


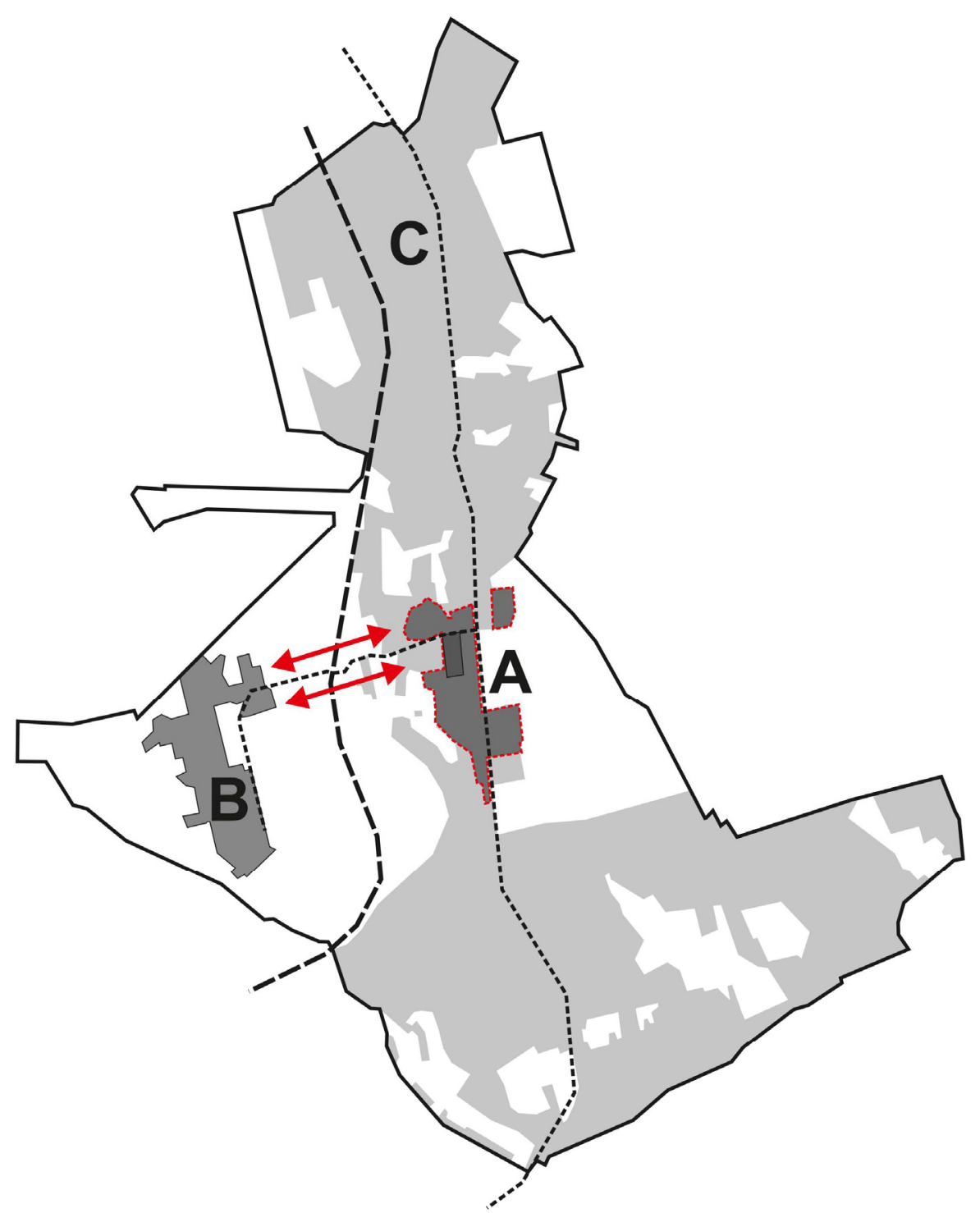

Fig. 1. The spatial layout of Nowa Dęba. Marking: A - embryo / core of residential and service tissue (mainly multi-family housing), city center, B - industrial area, DEZAMET's location (formerly Ammunition Factory No. 3) and other, smaller pre-fabrication also several local services and an estate (three buildings), C - Dęba village (own work).

\subsection{Development and spatial transformation of Nowa Sarzyna}

Nowa Sarzyna was established at a similar time and in conditions similar to Nowa Dęba. In connection with the construction plan, as part of the Four Year Plan, chemical plants designed to manufacture explosives were indicated in the area of the village of Ruda Łańcucka, where the Nitroza Nitro Compounds Production Plant was to be established. At the same time, a housing and service estate was planned for professionals brought in from other areas: both managerial and engineering staff, as well as workers. 
Work began in 1938, and until the outbreak of war, an almost complete complex of buildings was constructed (in relation to the present state). Like other factory estates of that period, the urban layout was very modest, based on the linear rhythm on the north-south axis. The complex included two-storey, extremely intimate, residential buildings for employees, a working hotel and a casino with a restaurant. After closing the plant during the war, production was resumed in 1954. The building was completed with three residential buildings maintained in a similar aesthetics, a very interesting three-storey residential building with services on the ground floor as well as a fire brigade building, a nursery and Factory Community Centre. Both the nursery and the Community Centre are maintained in the socialist realist style, which is not visible in the urban layout of the factory estate [5].

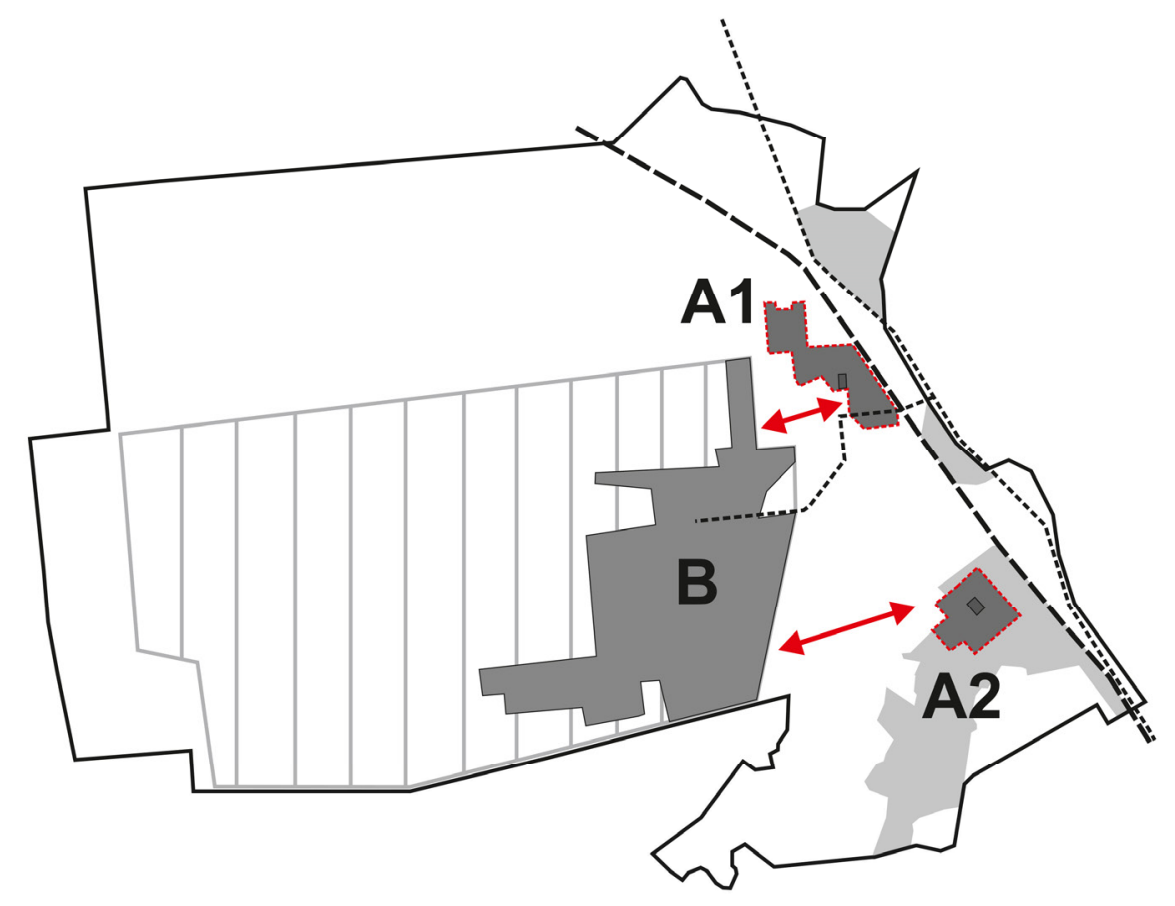

Fig. 2. The spatial layout of Nowa Sarzyna. Marking: A1 - the original urban area, a company estate, A2 - urban tissue was established in the second stage of the city development, currently the center, B industrial area, location of the CIECH-Sarzyna company (formerly NITROZA Sarzyna nitrocompounds factory) and heat and power plant (own study).

Unlike in Nowa Dęba, the housing and service structure of the city developed about $800 \mathrm{~m}$ below the estate as a separate unit. This was due to the heterogeneous land cover. Both the factory and the housing estate were built inside a forest complex. The new town used the unpopulated areas of the river valley located to the south. The buildings constructed here have an orthogonal character, regular on a rectangular plan. First, the eastern part was created, clearly referring to the style of early socialist modernism. The blocks were built to form a housing estate, at the same time separating something in the shape of semi-open quarters. Compositional elements are missing in this system, however, a representative public space located in front of the City Hall has been created over time. In 1973, Nowa Sarzyna obtained city rights. During this period (1970s, 1980s), the western part of the system was developed placing prefabricated buildings in comb systems. These blocks closed the composition. It should be emphasized that the urban layout of the second 
main center of Nowa Sarzyna is consistent, giving great opportunities to create a structural unit with high quality urban space. However, it would require the reconstruction of open areas, public space between buildings and a change in the color scheme of buildings to a less intensive one.

In the case of theindustrial plant, there was no fragmentation, only companies managing the enterprise changed along with a detailed profile of activity. The plant no longer produces explosives but plant protection agents, epoxy resins, polyester resins and silicone products [7].

\section{Summary}

When analyzing the functional and spatial structure of the Podkarpackie Voivodeship, it was found that specific small towns with an industrial plant - city (housing estate) model exist. This character results from the Four Year Plan, carried out in the 1930s, aimed at the economic recovery of the region through its introduction into its structure of industrial plants, mainly with an arms or machine and communication function. This policy resulted in the creation of characteristic units, such as: Stalowa Wola, Nowa Dęba, Nowa Sarzyna or Pustków. Although these settlements were created in similar circumstances ("in cruda radice"), each of them developed differently. In order to discuss the transformation profile, two units (Nowa Dęba and Nowa Sarzyna) were selected, which were granted city rights, but remained small towns with a population of up to 20000 inhabitants (Nowa Dęba around 11300 inhabitants, Nowa Sarzyna - around 6000 inhabitants).

The small towns mentioned above usually have a functional and compositional structure relatively easy to assess. It can be assumed that these units have retained the bipolar form (the system that creates the housing structure with an industrial plant, not the internal composition of the housing tissue) due to exceptional conditions. Often the element determining their development is the type of production, e.g. the production of weapons or dangerous materials. The context of their location is usually valuable natural areas, for example forests and wilderness designed to hide or isolate the urban complex.

The internal structure of the systems is usually relatively homogeneous. It can be assumed that large industrial plants located at the time of industrial prosperity were accompanied by buildings of modern character, both multi-family and single-family housing; whereas multi-family buildings preserved the form and layout characteristic of the 20th century in their entirety or in a fragment: both modernism and socialist modernism with elements of social realism.

The composition of the residential and service part is regular with no clearly outlined market - the main public space, which has evolved over time, yet has no clear edges as opposed to many cities with a historical origin. There is also the lack of a central height or residential dominant. With time, its function was taken over by the church built later, which, however, is clearly not part of the closed system. The drawback to the city is the limited number of areas for investment. The growth of the structure located in the forest requires obtaining permission every time to change its use as forest landto non-forest purposes, so the field reserve is small or even exhausted. At the same time, the intimacy of buildings can be helpful when the offer is extended to include tourist and recreational functions.

The field reserve accompanying the initially located plant gives opportunities for the development of entrepreneurship, in particular for manufacturing enterprises. The location in the insulated area ensures the maintenance of all protection, technical, sanitary and other areas, also in the case of plants that can significantly affect the environment.

By juxtaposing the features of the discussed cities, their development and spatial structure, one can try to indicate further directions for development of these unique 
settlement units. It seems that these cities could use their potential and become the centers of the third wave of the industrial revolution associated with innovation, creativity and new ecological technologies [8]. The high-tech industry already functions in these cities, so it would be possible to develop the idea of technopole, using the existing values of landscape and environment.

\section{References}

1. D. Szymańska, Urbanizacja na świecie, 121-142 (2007)

2. A. Kukliński, M. Najgrakowski, Miasto, 7-8 (163-164), 6-18 (1964)

3. S. Paradysz, Wiadomości Statystyczne, 6/2015, 54-65 (2015)

4. B. Bal-Domańska, E. Stanczyk, Prace Naukowe Uniwersytetu Ekonomicznego we Wrocławiu, 477, 11-23 (2017)

5. J. Morawski, W. Gurdak, L. Bogucka, Studium programowo - przestrzenne szlaku kulturowego Centralnego Okręgu Przemystowego na terenie województwa podkarpackiego, 20-22, 85-86 (2012-2013)

6. J. Pastuszczak, Miasto i gmina Nowa Dęba, 43-63 (2003)

7. M. Marczak - Sawicka, Nowa Sarzyna i okolice, 27-50, 57-69 (1998)

8. A. Sikora, M. Olejarz, Wybrane aspekty techniczne, ekonomiczne i ekologiczne wspótczesnego budownictwa, 167-180 (2016) 